\title{
INSTANTANEOUS TRANSPORT OF SALT, NUTRIENTS, SUSPENDED MATTER AND CHLOROPHYLL-a IN THE TROPICAL ESTUARINE SYSTEM OF SANTOS.
}

\author{
Gleyci A. O. Moser ${ }^{1}$; Sônia Maria Flores Gianesella ${ }^{2}$; José Juan Barrera Alba ${ }^{2}$; Alessandro Luvizon Bérgamo ${ }^{2}$; \\ Flávia M. P. Saldanha-Corrêa ${ }^{2}$; Luiz Bruner de Miranda ${ }^{2}$ \& Joseph Harari ${ }^{2}$ \\ ${ }^{1}$ Centro Universitário Monte Serrat, UNIMONTE \\ (Av. Alm. Saldanha da Gama, 89, 11030-400, Santos, SP, Brazil) \\ ${ }^{2}$ Instituto Oceanográfico, Universidade de São Paulo \\ (Praça do Oceanográfico, 191, 05508-120 São Paulo, SP, Brazil)
}

\begin{abstract}
A B S T R A C T
The contribution of the polluted São Vicente and Santos estuarine channels to the eutrophication of Santos bay was assessed through the quantification of instantaneous transport of salt, dissolved inorganic nitrogen (DIN) and phosphate, organic and inorganic matter (OSM and ISM) and chlorophyll- $a$ (Chl- $a$ ), during dry (austral winter- August/ 1999) and rainy (austral summerJanuary/2000) seasons. Samplings were carried out during spring and neap tides, in flood and ebb phases, in two transversal sections at the mouths of the São Vicente and Santos channels. Instantaneous transport values generally indicated importation of salt to the estuarine channels, exportation of DIN to the bay, mainly as $\mathrm{N}^{-\mathrm{NH}_{4}}$, at a maximum rate of $1155.1 \mathrm{~g} \mathrm{~s}^{-1}$ during the rainy season; importation of phosphate during the dry season (maximum of $385 \mathrm{~g} \mathrm{~s}^{-1}$ ) and exportation of ISM, OSM and Chl- $a$ during periods of greater freshwater discharge. These results demonstrate the great contribution made by the Santos and São Vicente estuaries to the eutrophication of Santos bay, especially in the rainy season.
\end{abstract}

\section{R ESUMO}

A contribuição dos canais estuarinos de Santos e São Vicente para a eutrofização da baía de Santos foi avaliada quantificando-se o transporte instantâneo de sal, fosfato e nitrogênio inorgânico dissolvido (NID), material em suspensão orgânico (MSO) e inorgânico (MSI) e clorofila-a, durante a estação seca (inverno austral- Agosto/1999) e chuvosa (verão austral- Janeiro/ 2000). As amostragens foram realizadas em períodos de sizígia e quadratura, durante as marés enchentes e vazantes, nas secções transversais das bocas dos canais de São Vicente e Santos. Os valores de transporte instantâneo obtidos durante o período de amostragem indicaram exportação de NID, principalmente sobre a forma de $\mathrm{N}-\mathrm{NH}_{4}$ (valor máximo de $1155,1 \mathrm{~g} \mathrm{~s}^{-1}$ ) na estação chuvosa; importação de fosfato durante a estação seca (máximo de $385,6 \mathrm{~g} \mathrm{~s}^{-1}$ ) e exportação de MSI, MSO e clorofila-a em períodos de maior contribuição fluvial. Estes resultados indicam uma importante contribuição dos canais estuarinos de Santos e São Vicente para a eutrofização da baía de Santos, especialmente durante o período chuvoso.

Descriptors: Instantaneous transport, Santos bay, Suspended matter, Chlorophyll, Dissolved inorganic nutrients, Eutrophication, Tropical estuaries.

Descritores: Transporte instantâneo, Baía de Santos, Material em suspensão, Clorofila, Nutrientes inorgânicos dissolvidos, Eutrofização, Estuários tropicais.

\section{INTRODUCTION:}

Growing human populations and associated infrastructure in coastal areas may be slowly destroying the balance between terrestrial and marine environments. Among these human pressures, the eutrophication caused by sewage input, as well as urban and agricultural runoff has been highlighted as a major global problem requiring urgent action (Graham et al., 2000). Land-sea interface processes

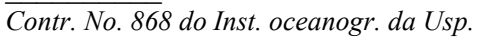

are especially reinforced in estuaries due to wide gradients in physical, chemical and biological parameters.

According to Dame \& Allen (1996), in a review on exchanges of inorganic and biological material between estuaries and the sea, the earliest ecological interest in this subject began with the first quantitative metabolic study on the highly productive salt marshes that dominate the bar-built estuaries of the Carolina Georgia Bight (Teal, 1962). Many authors have, since then, focused on this theme, most of them dealing with temperate estuarine systems, thus 
contributing to the understanding of the carbon cycle and the eutrophication process in coastal areas. Knowledge regarding temperate estuaries has been greatly increased by the studies of Mitchell et al. (1998), Uncles et al. (1998a), Grelowski et al. (2000), Jiang et al. (2000) and Wu et al. (2004).

Concerning tropical and sub-tropical estuaries, a number of studies have been undertaken in Australia, generally focusing on nutrient dynamics (Eyre, 1998; Eyre \& Balls, 1999), but the environments concerned present strongly episodic characteristics, unusual in other tropical estuaries. Worldwide carbon and nutrient balance data on tropical coastal areas derived from the LOICZ Project (Land-Ocean Interactions in the Coastal Zone) give some idea of the considerable exportation of nutrients to the adjacent marine areas (e.g. Rodriguez, 1999).

Even with the enhancement of eutrophication occurring at some particular sites on the Brazilian coast after the industrial boom of the 70's, only a few studies on the transport of properties have been carried out. Miranda et al. (1998) studied the salt transport in the Bertioga channel, which is also part of the same estuarine complex system studied in this paper (Fig. 1). Pereira-Filho et al. (2001), BarreraAlba et al. (2002) have studied transport of nutrients, seston and Chl- $a$ in tropical and sub-tropical estuarine systems in Brazil.

The present work is the first effort to evaluate the transport of volume and salt simultaneously with properties like phosphate and total dissolved inorganic nitrogen (DIN), inorganic and organic suspended matter (ISM and OSM, respectively) and Chl- $a$, in the tropical estuarine channels of São Vicente and Santos, to estimate their contribution to the eutrophication of the adjacent Santos bay.

\section{Material and Methods}

\section{Study Area}

The Estuarine System of Santos is located on the Southeastern Brazilian Coast $\left(23^{\circ} 53^{\prime}-24^{\circ} 02\right.$ 'S, $46^{\circ} 27^{\prime}-46^{\circ} 15^{\prime} \mathrm{W}$ ) and consists of 3 major estuarine channels, those of São Vicente, Santos and Bertioga, interconnected at the inner portion of the area (Fig. 1). The Santos and São Vicente estuarine channels cover an approximate area of $44,100 \mathrm{~m}^{2}$, with an average depth of $15 \mathrm{~m}$ in the central, dredged channel of Santos and $8 \mathrm{~m}$ in the São Vicente channel. Mean freshwater discharge data is only available for the Santos estuarine channel, and varies from $24 \mathrm{~m}^{3} / \mathrm{s}$ to $127 \mathrm{~m}^{3} / \mathrm{s}$, including those for both the Cubatão river and Henry Borden plant discharges (SONDOTECNICA, 1977). Tidal amplitude varies from $0.5 \mathrm{~m}$ to $1.5 \mathrm{~m}$
Climate is wet tropical with rainfall levels in the range of $2000 \mathrm{~mm}$ to $4500 \mathrm{~mm}$ per year, with high variation from year to year. Daily rainfall average in the driest season is around $10 \mathrm{~mm}$ whereas in the rainy season values are between 30.1 and $180 \mathrm{~mm}$ (DAEE, 1999). Actually there is no true dry season, but in the present paper, to enable the reader to distinguish it easily, the period of lower rainfall is here referred to as the "dry" season. The rainy season is actually, then, the period of heaviest rainfall.

The Santos Estuarine System is an area of intense urban, industrial and port activity. A petrochemical pole and many other industries, including fertilizer and steel plants, are found in the inner part of this estuarine complex. The Santos channel is also home to the largest Latin American harbour. Since the end of the 70's, the domestic sewage of Santos city is disposed of through a submarine outfall (with an average discharge of $7 \mathrm{~m}^{3}$ $\mathrm{s}^{-1}$ ) in the center of Santos bay (Fig. 1). Clandestine domestic sewage is also originated in the slums on the channels' borders and is a significant source of eutrophication (Braga et al., 2000).

Sampling:

Samplings were conducted in August/1999 (dry season) and January/2000 (rainy season), during consecutive spring and neap tidal cycles. Sampling stations were located in sections normal to the estuarine flow in both the São Vicente and Santos channels, at $100 \mathrm{~m}$ intervals. The São Vicente channel mouth is approximately $300 \mathrm{~m}$ wide and $6 \mathrm{~m}$ deep and the Santos channel approximately $500 \mathrm{~m}$ wide and 12 $\mathrm{m}$ deep. Thus, three stations were established in the São Vicente channel (stations 1, 2 and 3, respectively, from the left to the right side) and five in the Santos channel (stations 4, 5, 6, 7 and 8 from the left to the right) (Fig. 1).

Rainfall data were obtained by DAEE (Departamento de Águas e Energia Elétrica) from three meteorological stations in the area (Fig. 1). Bathymetry, temperature, salinity and current data were obtained on a first section run. On a second section run, the water was sampled for chemical and biological variables. Both sections were undertaken within an interval of less than one hour, during the flood and ebb tidal runs, according to the tide forecast. Finally, the tides predicted were compared to the tidal level as recorded by a tide gauge located in the Santos channel (Fig. 2). Temperature and salinity were measured by a multiparameter system for monitoring water quality $\left(\mathrm{HORIBA}^{\circledR}\right.$, model U22), at every $5 \mathrm{~m}$ depth. The salinity data obtained by HORIBA ${ }^{\circledR}$ were calibrated with salinity data from some discrete samples analyzed by the conductivity ratio (Beckman model RS-7C), converted into salinity units according to the UNESCO (1981) tables. 


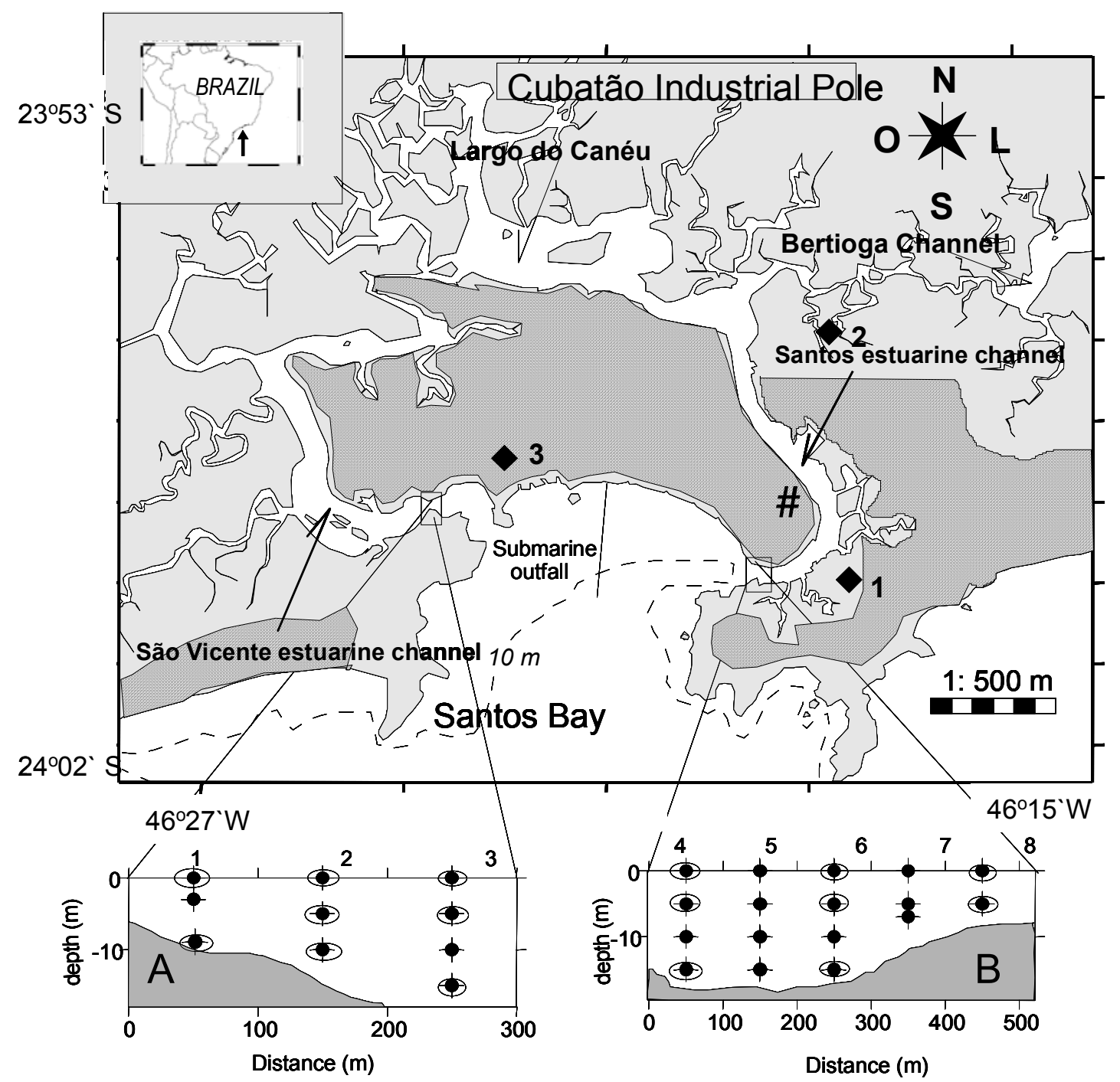

Urban Area

\# Tidal Gauge

Hydrographic stations

Submarine outfall

Pluviometric Stations

Water sampling

Fig. 1. Study area, Santos Estuarine System and sampling sites. The stations of the estuarine mouths are indicated in A- São Vicente estuarine channel mouth and B- Santos estuarine channel mouth. The locations of the tidal gauge, pluviometric stations, submarine outfall and urban areas are indicated on the map.

Current velocities and direction were obtained using a Braystoke ${ }^{\circledR}$ current meter at the same depth intervals. Velocity values were decomposed into their longitudinal and transversal components. As the Santos and São Vicente channels' mouths are on opposite sides of the Santos bay (Fig. 1), positive values of the longitudinal velocity component (u) represent an upstream flow for the Santos estuarine channel and downstream flow in the São Vicente estuarine channel. 

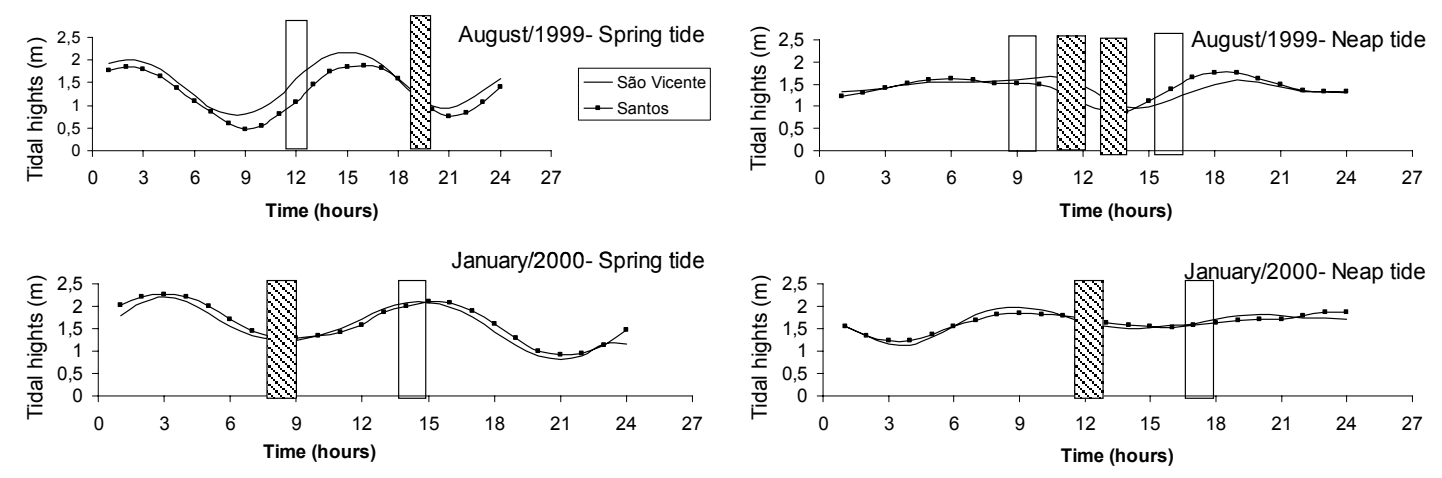

Fig. 2. Tidal variation during the spring and neap tidal experiments in August/1999 and January/2000, in the São Vicente (SV) and Santos (S) estuarine channels. The square indicates the sampling time in ebb (striped) and flood (white) tides.

Water for chemical and biological analyses was sampled at three stations in each channel mouth (stations 1, 2 and 3, in the São Vicente channel and 4, 5 and 8, in the Santos channel) with Van Dorn bottles. The sampling depths for chemical and biological data were based on light penetration measurements by Secchi disk readings (Poole \& Atkins, 1929). These depths were chosen according to the light penetration at the levels of $100 \%, 50 \%, 25 \%, 15 \%$, $7.5 \%, 1 \%$ and $0.5 \%$ of light attenuation, plus one depth close to the bottom. Seawater samples $(500 \mathrm{~mL})$ were filtered using Whatman ${ }^{\circledR} \mathrm{GF} / \mathrm{F}$ glass fiber filters for Chl- $a$, OSM and ISM determinations. Filtered water was taken for nutrient analysis. Filters and filtered water (kept in polyethylene flasks) were maintained at $-20^{\circ} \mathrm{C}$ until the time for laboratory analysis.

Nitrate, nitrite and ammonium were analyzed by the spectrophotometric method described in Aminot \& Chaussepied (1983) and total dissolved inorganic nitrogen was the sum of these inorganic compounds. Phosphate was determined by the spectrophotometric method described in Grasshoff et al. (1983).

Organic (OSM) and inorganic (ISM) suspended matter were analyzed by the gravimetric method as described in APHA (1985). Chl- $a$ was analyzed in accordance with Jeffrey \& Humphrey (1973).

\section{Statistical Analysis:}

For the comparison of the results, Pearson's correlation coefficient was applied to the data set. The calculations were performed using Statistica software (version 5.0 for Windows).

\section{Transport Computation:}

The transport calculation was carried out in accordance with the programs developed by Bérgamo et al. (2002). The longitudinal component of current velocity, salinity, phosphate, DIN, ammonium, OSM, ISM and Chl- $a$ data were all fitted by cubic spline into matrices with a horizontal space of $100 \mathrm{~m}$ and vertical resolution of $5 \mathrm{~m}$, all transformed into adimensional depths ( 0.1 intervals).

Volume transport $\left(T v, \mathrm{~m}^{3} \mathrm{~s}^{-1}\right)$ was computed by the following expression (Miranda et al. 1998):

$$
T v=\iint_{A} u d A
$$

where: $u$ is the longitudinal velocity component averaged in space $\left(\mathrm{m} \mathrm{s}^{-1}\right)$, and $A$ is the transversal area of the channel $\left(\mathrm{m}^{2}\right)$.

The mass transport properties $\left(T_{P}, \mathrm{~g} \mathrm{~s}^{-1}\right)$, through a channel section normal to the longitudinal flow of the estuarine channel, are equal to:

$T_{p}=\iint_{A} P \cdot u d A$

where: $P$ is the property (phosphate, DIN, ammonium, OSM, ISM and Chl-a) concentration averaged in space.

For the salt transport $\left(\mathrm{kg} \mathrm{s}^{-1}\right)$ calculation, equation (2) was multiplied by density, since salinity is an adimensional property.

As the São Vicente and Santos estuarine channels are not laterally homogeneous, the sampling was undertaken in a section normal to the flow, during the flood and ebb tides. The mass transport calculation 
(equation 2), in a section normal to the estuarine flow, followed the following steps:

1) Calculation of the instantaneous advective mass transport of a property (Mp), through a unit width of an estuarine channel section:

$$
M p=\int_{0}^{h} P u d h=\overline{P u} \cdot h \quad \mathrm{~g} \mathrm{~s}^{-1}
$$

where $P, u$ and $h$ are the property concentration, the longitudinal velocity component and the water column depth, respectively. The over-bar indicates the variable mean over the total depth of the water column.

2) Calculation of the mass transport through the total width of the estuarine channel section (L):

$$
T T_{P}=\int_{0}^{L} M_{P} d L \quad \mathrm{~g} \mathrm{~s}^{-1}
$$

The balance of properties between each of the estuarine channels and Santos bay is given by the difference between the vectors of instantaneous transport on flood and ebb tidal runs. When the vectors lay in the same direction their values were added together.

\section{RESUlts:}

Dry Season

Climatological conditions during the sampling period were typical for the dry season, the rainfall levels were below $2 \mathrm{~mm}$ day $^{-1}$ at both tides (Fig. 3). The euphotic zone was deeper in the Santos channel, at both spring and neap tides.

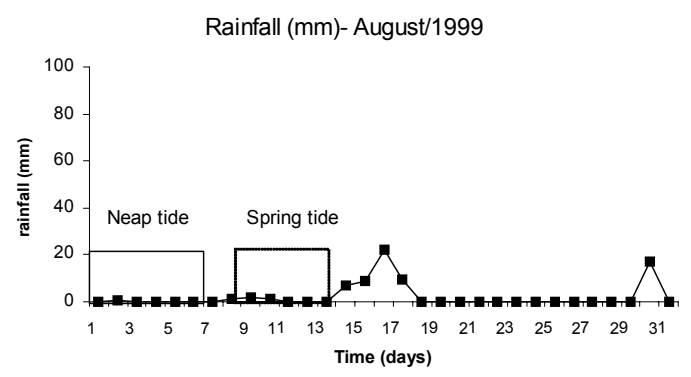

During the ebb phase current velocities increased in the center of the São Vicente channel, lesser vertical stratification was observed in this channel transect, but most of the time the vertical current structure was partially mixed or even vertical homogeneous in both channel mouths (Figs 4 and 5). In the flood periods the Santos channel showed higher current velocities than the São Vicente channel, where the inflow occurred mainly along the left margin during the spring flood tides. A different condition was observed in the circulation pattern in the Santos channel during the neap flood tide, where less saline water (25.2) flowed out of the channel along the left margin.

Water temperature was around $20^{\circ} \mathrm{C}$ during the surveys in both channels. Salinity, dissolved inorganic nutrients and particulate compounds varied substantially according to the tidal conditions and as between channels (Table 1). Salinity average values ranged from 26.8 to 31.9 . Low salinity values were recorded in the São Vicente channel, generally related to high ebb tide current velocities.

Dissolved inorganic nutrients, especially nitrogenous compounds, were related to increases in the freshwater contribution in both channels, presenting a negative correlation with salinity (Table 2 ). The highest concentration of DIN was recorded in the São Vicente channel during neap tide, ebb phase, related to low salinity. However, in Santos channel the concentrations were high in the flood phases. Ammonium represented from $25 \%$ to $90 \%$ of DIN, the major contributions generally being observed in the ebb phases. In the dry season phosphate was generally associated with flood tides. Although the correlation was not significant, phosphate was positively related to salinity (Table 2).

ISM and OSM were greater in the ebb phases. On the other hand, the highest chlorophyll values were generally observed in the flood periods (Table 1).

Rainfall (mm)- January/2000

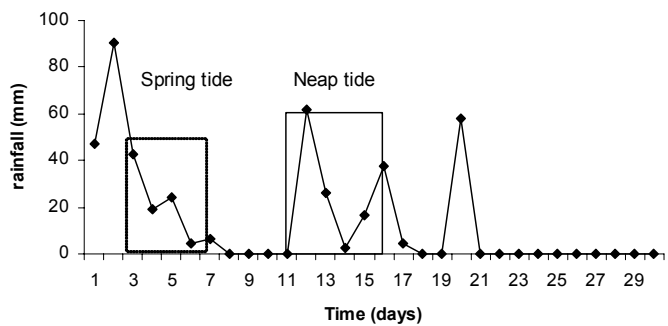

Fig. 3. Rainfall level in August/1999 and January/2000, the square indicates the sampling period during spring and neap tides. 


\section{Current Velocity (m s-1)}

Dry Season (August/1999)

right margin

\section{A) Spring ebb tide}

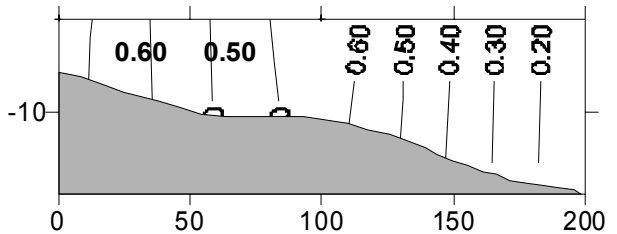

C) Neap ebb tide

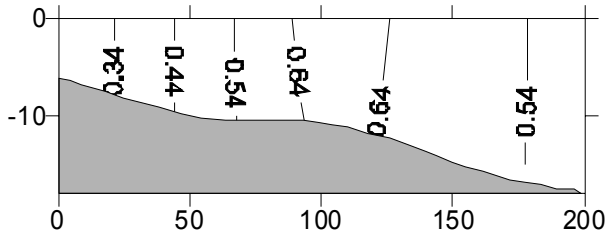

$\widehat{\underline{\xi}}$

E) Spring ebb tide

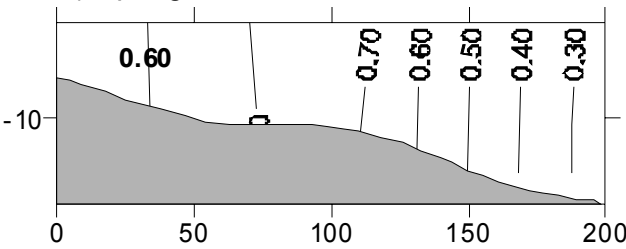

G) Neap ebb tide

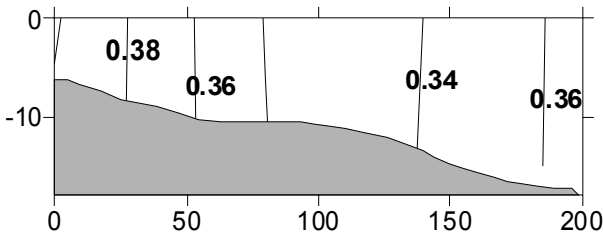

right margin

left margin

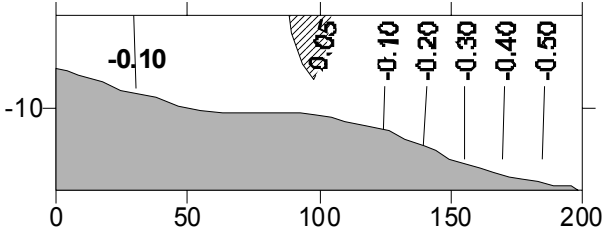

E) Neap flood tide

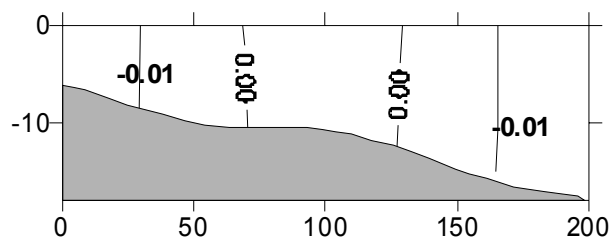

Rainy Season (January/2000)

\section{F) Spring flood tide}

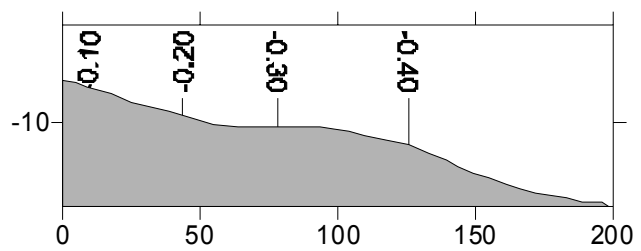

H) Neap flood tide

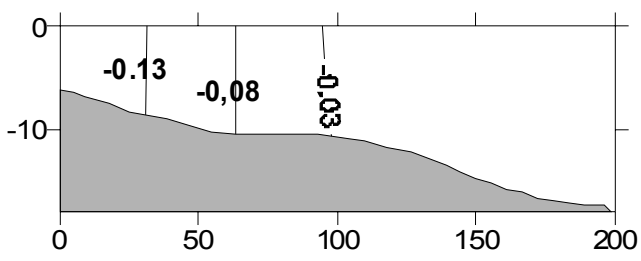

Distance $(\mathrm{m})$

Fig.4. Current velocity $\left(\mathrm{m} \mathrm{s}^{-1}\right)$ profiles across the São Vicente estuarine channel mouth during spring (A, B) and neap tide (C, D) in August/1999 and in spring (E, F) and neap tide (G, H) in January/2000, at ebb (left columns) and flood (right columns) phases. Positive values indicate downstream currents and negative velocities indicate upstream ones. The striped pattern indicates opposite flux in flood and ebb tides.

Rainy Season:

The climatic conditions observed in this period showed rainfall levels as high as those obtained between 1977 and 1998 (DAEE, 1999). One day before the beginning of the spring tide sampling, in the
Santos channel, precipitation of $80 \mathrm{~mm}^{-1 a y^{-1}}$ occurred. Also at the neap tide, high rainfall values were recorded throughout the sampling period, in both estuarine channels (maximum of $60 \mathrm{~mm}^{\text {day }}{ }^{-1}$ ) (Fig. 3 ). The rain affected the euphotic zone, especially in the Santos channel (Tab. 1). 
Current Velocity (m s-1)

Dry Season (August/1999)

left margin

right margin

left margin

right margin

A) Spring ebb tide

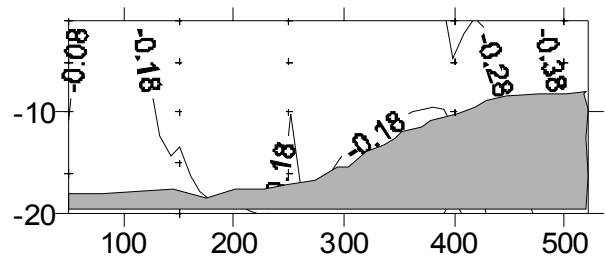

C) Neap ebb tide

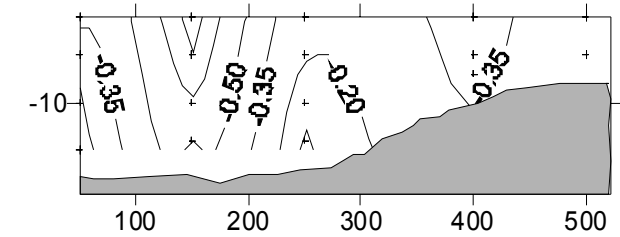

ڤิ

E) Spring flood tide

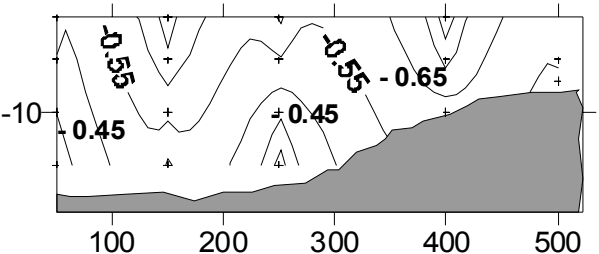

G) Neap ebb tide

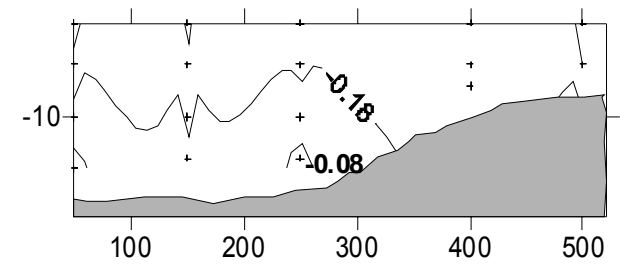

B) Spring flood tide

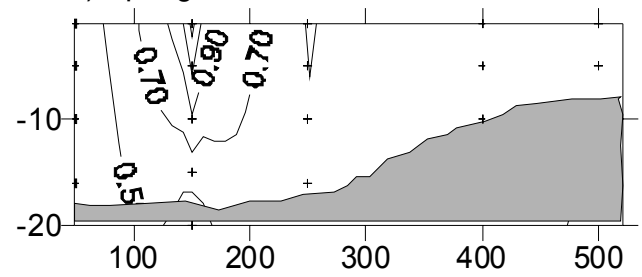

D) Neap flood tide

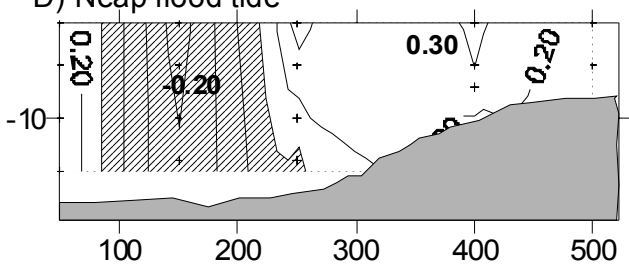

Rainy Season (January/2000)

\section{F) Spring flood tide}

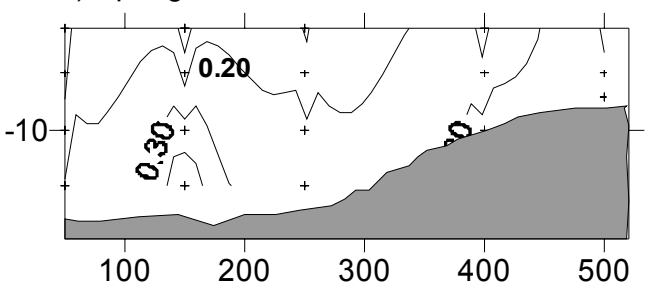

H) Neap flood tide

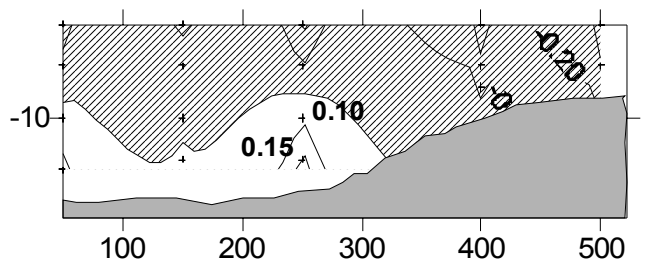

Distance (m)

Fig.5. Current velocity $\left(\mathrm{m} \mathrm{s}^{-1}\right)$ profiles across the Santos estuarine channel mouth during spring (A, B) and neap tide (C, D) in August/1999 and in spring (E, F) and neap tide (G, H) in January/2000, in ebb (left columns) and flood (right columns) phases. Positive values indicate upstream currents and negative velocities indicate downstream ones. The striped pattern indicates opposite flux in flood and ebb tides.

Maximum current velocities were recorded in the São Vicente channel during the spring tide, ebb period. In this channel, high values were generally observed in the central portion during the ebb tide, and at the margins during the flood tide. As during the dry season, current profiles were vertical homogeneous (Fig. 4). In the Santos channel current profiles were more highly stratified when velocities increased at the water surface. A reverse flow was observed in the surface waters during the neap flood tide (Fig. 5). 
Water temperature values were around $27^{\circ} \mathrm{C}$ (Table 1) and no thermal stratification was detected (Moser et al., 2002). Generally, salinity was higher during flood phases, maximum values were registered in the Santos channel.

DIN, represented mainly by ammonium in ebb phases, increased in the rainy season, in both estuarine channels (Tables 1 and 2). Phosphate concentrations were lower than those obtained during the dry season. Higher concentrations were observed during the ebb phases of the spring tides, in both channels (Table 1).

In general, particulate compounds were related to ebb phases, during both spring and neap tides (Table 1). OSM presented a significant positive correlation with temperature (Table 2), probably because high values were observed during the summer, rainy season, when water temperatures were $5^{\circ}$ to $9^{\circ} \mathrm{C}$ higher than in the winter, dry season. The maximum chlorophyll concentration $\left(97.4 \mathrm{mg} \mathrm{m}^{-3}\right)$ was observed in the Santos estuarine channel, during the ebb phase of the neap tide. A bloom of Skeletonema costatum, an opportunistic centric diatom, occurred in this occasion (Moser et al., 2002).

\section{Transport of Material}

São Vicente Channel

During the dry season, the volume transport in the São Vicente channel increased with the flood tides, both in spring and neap conditions (Table 3). The rainfall during January produced an inversion in this current pattern, reverting the movement observed in the dry season.

As expected in the dry season sampling, in the São Vicente channel the instantaneous transport salt balance between flood and ebb tides was towards the channel, both under spring and neap tidal conditions. Phosphate was imported from the bay during the dry season, while DIN and ammonium were exported into the bay. Due to the heavy rainfall observed in January, all the dissolved compounds, including salt, showed instantaneous transport towards the bay (Table 3).

During the neap tides in the rainy season, the outwelling of particulate compounds increased due to high freshwater discharge. An inwelling of these properties into the São Vicente channel occurred only with the spring tide in the dry season.

Table 1. Mean values and standard deviation for temperature $\left({ }^{\circ} \mathrm{C}\right)$, salinity $\left(\mathrm{g} \mathrm{L}^{-1}\right)$, DIN $\left(\mathrm{g} \mathrm{L}^{-1}\right)$, phosphate $\left(\mathrm{g} \mathrm{L}^{-1}\right), \operatorname{ISM}\left(\mathrm{mg} \mathrm{L}^{-1}\right)$, chlorophyll-a $\left(\mu \mathrm{g} \mathrm{L}^{-1}\right)$ and Zeu $(\mathrm{m})$ for the period of study in the São Vicente and Santos estuarine channels.

\begin{tabular}{|c|c|c|c|c|c|c|c|c|c|}
\hline \multirow{2}{*}{$\begin{array}{l}\text { São Vicente Estuarine Channel } \\
\text { Spring Tide }\end{array}$} & \multicolumn{9}{|c|}{ AUGUST-DRY SEASON } \\
\hline & $\begin{array}{c}\text { Temperature } \\
{ }^{\circ} \mathrm{C}\end{array}$ & Salinity & $\begin{array}{c}\text { Ammonium } \\
g L^{-1}\end{array}$ & $\begin{array}{l}D I N \\
g L^{-1}\end{array}$ & $\begin{array}{c}\text { Phosphate } \\
g L^{-1}\end{array}$ & $\begin{array}{l}I S M \\
m g L^{-1}\end{array}$ & $\begin{array}{c}O S M \\
m g L^{-1}\end{array}$ & $\begin{array}{c}\text { Chlorophyll } \\
\mu g L^{-1}\end{array}$ & $\begin{array}{c}\text { Zeu } \\
m\end{array}$ \\
\hline Ebb & $20.9( \pm 0.2)$ & $28.37( \pm 0.8)$ & $2.6 \times 10^{-4}\left( \pm 1 \times 10^{-4}\right)$ & $8.4 \times 10^{-4}\left( \pm 4.4 \times 10^{-4}\right)$ & $1.1 \times 10^{-4}\left( \pm 2.7 \times 10^{-5}\right)$ & $52.1( \pm 11.1)$ & $6.56( \pm 2.8)$ & $7.1( \pm 5.4)$ & $2.8( \pm 0.0)$ \\
\hline Flood & $20.7( \pm 0.1)$ & $31.4( \pm 0.2)$ & $3.7 \times 10^{-5}\left( \pm 1.2 \times 10^{-5}\right)$ & $3.5 \times 10^{-4}\left( \pm 8.6 \times 10^{-5}\right)$ & $3.4 \times 10^{-4}\left( \pm 7.6 \times 10^{-5}\right)$ & $63.5( \pm 17.8)$ & $4.5( \pm 3.5)$ & $8.4( \pm 0.9)$ & $2.8( \pm 0.0)$ \\
\hline \multicolumn{10}{|l|}{$\begin{array}{l}\text { Neap Tide } \\
\end{array}$} \\
\hline Ebb & $20.5( \pm 0.1)$ & $29.2( \pm 2.0)$ & $3.2 \times 10^{-4}\left( \pm 1.3 \times 10^{-4}\right)$ & $1.2 \times 10^{-3}\left( \pm 4.5 \times 10^{-4}\right)$ & $2.7 \times 10^{-4}\left( \pm 1.0 \times 10^{-4}\right)$ & $47.2( \pm 21.9)$ & $4.1( \pm 1.8)$ & $12.1( \pm 10.6)$ & $2.8( \pm 0.0)$ \\
\hline Flood & $19.7( \pm 0.3)$ & $26.8( \pm 1.5)$ & $2.2 \times 10^{-4}\left( \pm 1.6 \times 10^{-4}\right)$ & $8.9 \times 10^{-4}\left( \pm 3.8 \times 10^{-4}\right)$ & $2.1 \times 10^{-4}\left( \pm 8.1 \times 10^{-5}\right)$ & $17.1( \pm 15.6)$ & $1.5( \pm 1.6)$ & $3.2( \pm 1.7)$ & $2.8( \pm 0.0)$ \\
\hline \multicolumn{10}{|l|}{$\begin{array}{l}\text { Santos Estuarine Channel } \\
\text { Spring Tide }\end{array}$} \\
\hline Ebb & $20.5( \pm 0.1)$ & $31.9( \pm 0.1)$ & $3.6 \times 10^{-5}\left( \pm 2 \times 10^{-5}\right)$ & $2.0 \times 10^{-4}\left( \pm 4.1 \times 10^{-5}\right)$ & $8.6 \times 10^{-5}\left( \pm 1.4 \times 10^{-5}\right)$ & $50.5( \pm 26.4)$ & $4.6( \pm 2.1)$ & $8.7( \pm 2.2)$ & $3.4( \pm 0.1)$ \\
\hline Flood & $20.7( \pm 0.1)$ & $31.7( \pm 0.6)$ & $2.0 \times 10^{-5}\left( \pm 8.1 \times 10^{-6}\right)$ & $2.6 \times 10^{-4}\left( \pm 2.1 \times 10^{-4}\right)$ & $1.5 \times 10^{-4}\left( \pm 6.0 \times 10^{-5}\right)$ & $26.5( \pm 21.7)$ & $5.7( \pm 1.4)$ & $9.7( \pm 2.5)$ & $4.2( \pm 0.0)$ \\
\hline \multicolumn{10}{|l|}{ Neap Tide } \\
\hline Ebb & $20.4( \pm 0.2)$ & $28.8( \pm 1.4)$ & $2.2 \times 10^{-4}\left( \pm 1.4 \times 10^{-4}\right)$ & $4.7 \times 10^{-4}\left( \pm 2.8 \times 10^{-4}\right)$ & $2.5 \times 10^{-4}\left( \pm 1.8 \times 10^{-4}\right)$ & $39.8( \pm 12.4)$ & $4.1( \pm 6.9)$ & $5.5( \pm 0.6)$ & $5.6( \pm 0.3)$ \\
\hline Flood & $20.3( \pm 0.2)$ & $30( \pm 0.9)$ & $1.3 \times 10^{-4}\left( \pm 4.8 \times 10^{-5}\right)$ & $8.5 \times 10^{-4}\left( \pm 5.3 \times 10^{-4}\right)$ & $1.3 \times 10^{-4}\left( \pm 6.8 \times 10^{-5}\right)$ & $35.7( \pm 24.2)$ & $4.2( \pm 1.7)$ & $9.6( \pm 2.0)$ & $4.2( \pm 0.0)$ \\
\hline $\begin{array}{l}\text { São Vicente Estuarine Channel } \\
\text { Spring Tide }\end{array}$ & \multicolumn{9}{|c|}{ JANUARY-RAINY SEASON } \\
\hline Ebb & $25.5( \pm 0.1)$ & $25.6( \pm 2.4)$ & $1.9 \times 10^{-4}\left( \pm 2.6 \times 10^{-4}\right)$ & $1.8 \times 10^{-3}\left( \pm 6.5 \times 10^{-5}\right)$ & $1.4 \times 10^{-4}\left( \pm 4.1 \times 10^{-5}\right)$ & $72.8( \pm 31.7)$ & $11.5( \pm 5.0)$ & $7.8( \pm 1.8)$ & $5.0( \pm 0.0)$ \\
\hline Flood & $26.1( \pm 0.2)$ & $29.6( \pm 3.2)$ & $2.1 \times 10^{-4}\left( \pm 1.5 \times 10^{-4}\right)$ & $3.7 \times 10^{-4}\left( \pm 2.5 \times 10^{-5}\right)$ & $1.2 \times 10^{-4}\left( \pm 3.3 \times 10^{-5}\right)$ & $59.4( \pm 19.1)$ & $9.8( \pm 2.2)$ & $2.2( \pm 3.1)$ & $4.2( \pm 0.1)$ \\
\hline Neap Tide & & & & & & & & & \\
\hline Ebb & $27.8( \pm 0.3)$ & $30.7( \pm 3.7)$ & $4.7 \times 10^{-4}\left( \pm 3.4 \times 10^{-4}\right)$ & $7.5 \times 10^{-4}\left( \pm 4.9 \times 10^{-4}\right)$ & $1.1 \times 10^{-4}\left( \pm 7.4 \times 10^{-5}\right)$ & $55.9( \pm 24.2)$ & $13.4( \pm 1.1)$ & $11.2( \pm 3.9)$ & $4.2( \pm 0.0)$ \\
\hline Flood & $28.3( \pm 0.3)$ & $29.5( \pm 3.4)$ & $3.2 \times 10^{-4}\left( \pm 1.7 \times 10^{-4}\right)$ & $6.3 \times 10^{-4}\left( \pm 2.6 \times 10^{-4}\right)$ & $1.2 \times 10^{-4}\left( \pm 5.2 \times 10^{-5}\right)$ & $18.4( \pm 3.7)$ & $7.3( \pm 0.9)$ & $5.1( \pm 4.5)$ & $4.2( \pm 0.0)$ \\
\hline \multicolumn{10}{|l|}{$\begin{array}{l}\text { Santos Estuarine Channel } \\
\text { Spring Tide }\end{array}$} \\
\hline Ebb & $25.3( \pm 0.1)$ & $31.1( \pm 3.9)$ & $4.5 \times 10^{-4}\left( \pm 1.8 \times 10^{-4}\right)$ & $8.5 \times 10^{-4}\left( \pm 3.7 \times 10^{-4}\right)$ & $1.8 \times 10^{-4}\left( \pm 6.1 \times 10^{-5}\right)$ & $77.3( \pm 28.6)$ & $7.9( \pm 4.9)$ & $8.9( \pm 5.6)$ & $4.1( \pm 0.1)$ \\
\hline Flood & $25.8( \pm 0.2)$ & $33.5( \pm 2.7)$ & $4.5 \times 10^{-5}\left( \pm 3.7 \times 10^{-5}\right)$ & $7.7 \times 10^{-4}\left( \pm 5.2 \times 10^{-4}\right)$ & $6.4 \times 10^{-5}\left( \pm 3.4 \times 10^{-5}\right)$ & $52.4( \pm 43.3)$ & $5.9( \pm 3.2)$ & $6.8( \pm 2.9)$ & $4.2( \pm 0.0)$ \\
\hline \multicolumn{10}{|l|}{ Neap Tide } \\
\hline Ebb & $27.1( \pm 0.2)$ & $31.4( \pm 5.4)$ & $4.5 \times 10^{-4}\left( \pm 5.1 \times 10^{-5}\right)$ & $5.1 \times 10^{-4}\left( \pm 3.4 \times 10^{-4}\right)$ & $1.1 \times 10^{-4}\left( \pm 4.9 \times 10^{-5}\right)$ & $41.5( \pm 28.7)$ & $4.9( \pm 5.1)$ & $48.9( \pm 29.9)$ & $2.9( \pm 0.1)$ \\
\hline Flood & $27.1( \pm 0.4)$ & $32.6( \pm 4.5)$ & $1.4 \times 10^{-4}\left( \pm 5.2 \times 10^{-5}\right)$ & $4.8 \times 10^{-4}\left( \pm 3.7 \times 10^{-4}\right)$ & $1.2 \times 10^{-4}\left( \pm 9.3 \times 10^{-5}\right)$ & $41.0( \pm 5.7)$ & $12.9( \pm 0.9)$ & $24.7( \pm 22.3)$ & $2.8( \pm 0.0)$ \\
\hline
\end{tabular}


Table 2. Pearson's correlation matrix for the Santos and São Vicente estuarine channels, dry and rainy season data combined.

Marked correlations are significant at $\mathrm{p}<.05000$

$\mathrm{N}=17$

\begin{tabular}{|c|c|c|c|c|c|c|c|c|c|}
\hline & Temperature & Salinity & Ammonium & $D I N$ & Phosphate & $I S M$ & $O S M$ & Chlorophyll-a & Zeu \\
\hline \multirow[t]{2}{*}{ Temperature } & 1 & 0.2259 & 0.474 & 0.0782 & -0.0853 & 0.1992 & 0.7352 & 0.3461 & 0.1552 \\
\hline & p $=\ldots--$ & $\mathrm{p}=.383$ & $\mathrm{p}=.055$ & $\mathrm{p}=.766$ & $\mathrm{p}=.745$ & $\mathrm{p}=.443$ & $\mathrm{p}=.001$ & $\mathrm{p}=.174$ & $\mathrm{p}=.552$ \\
\hline \multirow[t]{2}{*}{ Salinity } & 0.2259 & 1 & -0.6266 & -0.657 & 0.3138 & 0.0394 & 0.0677 & 0.3369 & -0.1988 \\
\hline & $\mathrm{p}=.383$ & $P=---$ & $p=.004$ & $\mathrm{p}=.004$ & $\mathrm{p}=.220$ & $\mathrm{p}=.881$ & $\mathrm{p}=.796$ & $\mathrm{p}=.186$ & $\mathrm{p}=.444$ \\
\hline \multirow[t]{2}{*}{ Ammonium } & 0.474 & -0.6266 & 1 & 0.2852 & -0.3453 & 0.138 & 0.257 & 0.3436 & -0.025 \\
\hline & $\mathrm{p}=.055$ & $p=.004$ & $\mathrm{p}=\ldots--$ & $\mathrm{p}=.267$ & $\mathrm{p}=.175$ & $\mathrm{p}=.597$ & $\mathrm{p}=.319$ & $\mathrm{p}=.177$ & $\mathrm{p}=.924$ \\
\hline \multirow[t]{2}{*}{ DIN } & 0.0782 & -0.657 & 0.2852 & 1 & 0.0687 & 0.2957 & 0.1849 & -0.1312 & 0.1605 \\
\hline & $\mathrm{p}=.766$ & $p=.004$ & $\mathrm{p}=.267$ & $\mathrm{P}=---$ & $\mathrm{p}=.793$ & $\mathrm{p}=.249$ & $\mathrm{p}=.477$ & $\mathrm{p}=.616$ & $\mathrm{p}=.538$ \\
\hline \multirow[t]{2}{*}{ Phosphate } & -0.0853 & 0.3138 & -0.3453 & 0.0687 & 1 & 0.118 & -0.289 & -0.2055 & 0.0655 \\
\hline & $\mathrm{p}=.745$ & $\mathrm{p}=.220$ & $\mathrm{p}=.175$ & $\mathrm{p}=.793$ & p = --- & $\mathrm{p}=.652$ & $\mathrm{p}=.260$ & $\mathrm{p}=.429$ & $\mathrm{p}=.803$ \\
\hline \multirow[t]{2}{*}{ ISM } & 0.1992 & 0.0394 & 0.138 & 0.2957 & 0.118 & 1 & 0.4317 & -0.0521 & 0.1384 \\
\hline & $\mathrm{p}=.443$ & $\mathrm{p}=.881$ & $\mathrm{p}=.597$ & $\mathrm{p}=.249$ & $\mathrm{p}=.652$ & $\mathrm{P}=\ldots--$ & $\mathrm{p}=.084$ & $\mathrm{p}=.843$ & $\mathrm{p}=.596$ \\
\hline \multirow[t]{2}{*}{ OSM } & 0.7352 & 0.0677 & 0.257 & 0.1849 & -0.289 & 0.4317 & 1 & 0.0696 & 0.2301 \\
\hline & $p=.001$ & $\mathrm{p}=.796$ & $\mathrm{p}=.319$ & $\mathrm{p}=.477$ & $\mathrm{p}=.260$ & $\mathrm{p}=.084$ & $p=---$ & $\mathrm{p}=.791$ & $\mathrm{p}=.374$ \\
\hline \multirow{2}{*}{$\begin{array}{l}\text { Chlorophyll- } \\
\text { a }\end{array}$} & 0.3461 & 0.3369 & 0.3436 & -0.1312 & -0.2055 & -0.0521 & 0.0696 & 1 & -0.4023 \\
\hline & $\mathrm{p}=.174$ & $\mathrm{p}=.186$ & $\mathrm{p}=.177$ & $\mathrm{p}=.616$ & $\mathrm{p}=.429$ & $\mathrm{p}=.843$ & $\mathrm{p}=.791$ & $\mathrm{P}=\ldots--$ & $\mathrm{p}=.109$ \\
\hline \multirow[t]{2}{*}{ Zeu } & 0.1552 & -0.1988 & -0.025 & 0.1605 & 0.0655 & 0.1384 & 0.2301 & -0.4023 & 1 \\
\hline & $\mathrm{p}=.552$ & $\mathrm{p}=.444$ & $\mathrm{p}=.924$ & $\mathrm{p}=.538$ & $\mathrm{p}=.803$ & $\mathrm{p}=.596$ & $p=.374$ & $\mathrm{p}=.109$ & $\mathrm{p}=\ldots--$ \\
\hline
\end{tabular}

\section{Santos Channel}

In the Santos channel, in the dry season, volume transport increased in the flood periods of the spring tides (Table 3) while in the rainy season the inversion of the current pattern, during the neap tide, reverted the movement observed in the dry season.

During the dry season, the salt balance was towards the Santos channel (Table 3). Phosphate, ammonium and DIN were exported on the neap tide and imported on the spring tide.

In the rainy season reversed current orientations were observed in the Santos channel, due to the heavy rainfall and low tidal variations $(0.1 \mathrm{~m})$. Consequently, all the dissolved compounds, including salt, were exported into the Santos bay (Table 3). The particulate compounds followed the same pattern described for the São Vicente channel (Table 3).

\section{Discussion}

The present data characterize the Santos Estuarine System as a typical tropical ecosystem, as defined by Eyre and Balls (1999). The following key characteristics of tropical estuaries were observed in this system: high mean temperatures with wider variation along the salinity gradient, almost $10^{\circ} \mathrm{C}$ according to Moser et al. (2001) as against variations lower than $1^{\circ} \mathrm{C}$ in temperate estuaries (Eyre \& Balls; 1999), high rainfall, low light penetration and mangroves as the predominant intertidal vegetation.

High variable flows observed in both dry and rainy seasons are characteristic of tropical systems (Eyre \& Balls, 1999), reflected in increases in the terrestrial material transported to the estuaries, changes in hydrology and flushing times. Important outwelling events into the Santos bay were associated with current asymmetries observed during the rainy season. These asymmetries, such as conditions of convergence and divergence are common to all tidal cycle (Harari \& Camargo, 1997; Harari et al., 2000) and reproduce alterations in the flow in both channels.

Though the temporal accuracy was limited in the present study as sampling was performed only once at ebb and flood phases, generally at their greatest flux, in the dry and rainy seasons, the data represent an accurate spatial approximation to the instantaneous transport of properties, bearing in mid the samplings performed along the whole transversal section of the estuarine channels; since neither the São Vicente nor the Santos estuary can be regarded as laterally homogeneous. 
Table 3. Values of volume transport and transport of properties during ebb tide, flood tide and balance in the São Vicente and Santos channel mouths. For São Vicente, positive values indicate exportation into Santos bay and negative ones importation from this bay. For Santos, negative values indicate exportation into Santos bay and positive ones importation from this bay.

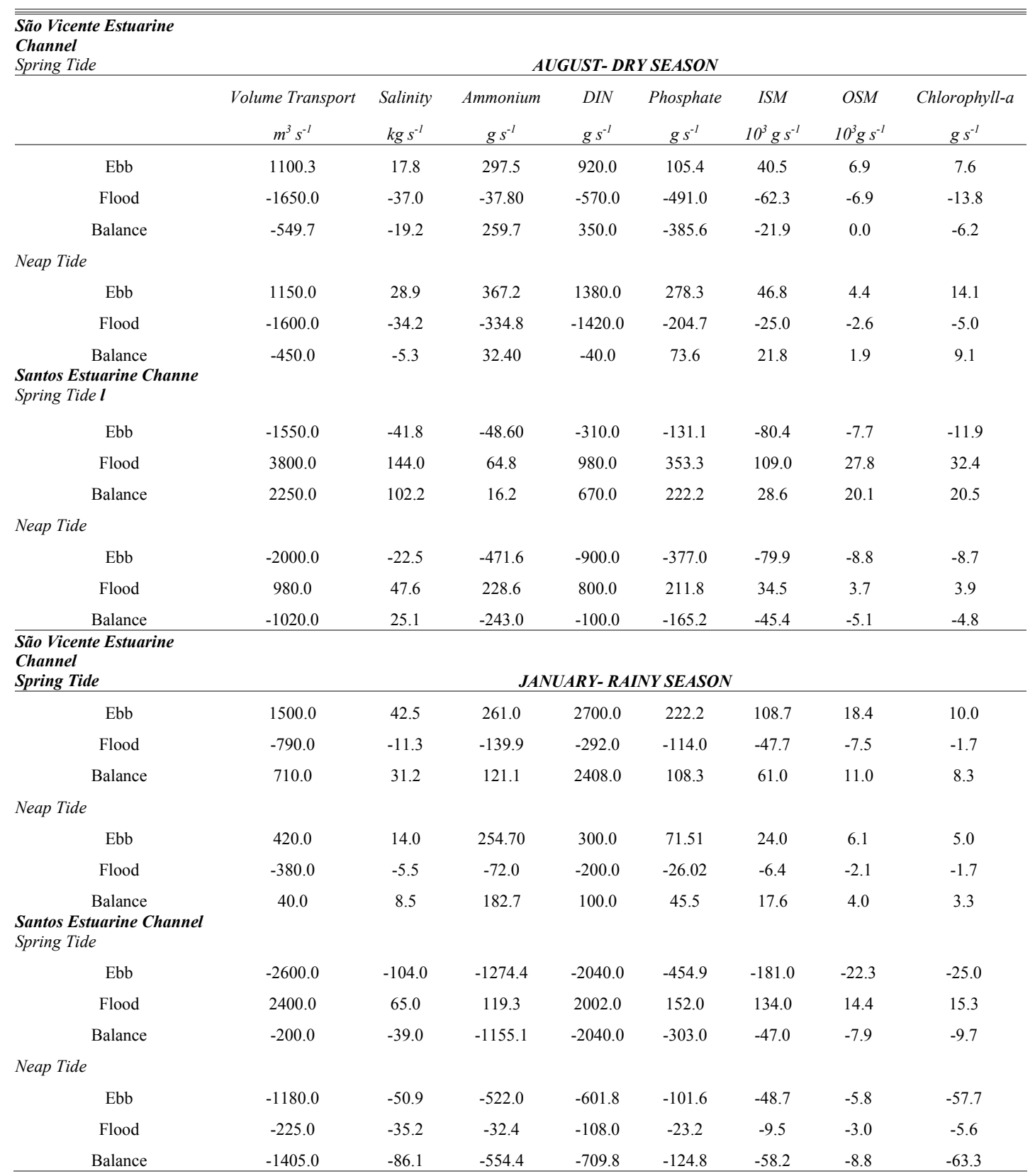

Rainfall played an important role both in the volume transport and in the hydrodynamic characteristics of the system, increasing inorganic nitrogen compounds and suspended matter in the inner portion of the system and promoting the outwelling of dissolved and particulate matter. The instantaneous

salt transport observed in the present study was similar to that observed in the Bertioga channel (Miranda et al., 1998) in spite of the distinct tributaries and drainage basins of these channels, the similar salt transport being related to their physiographical similarities. 
The predominant form of DIN was ammonium, related mainly to fluvial inflow (correlation with salinity $=-0.63, \mathrm{p}=0.004$ ), with values as high as $9.9 \times 10^{-4} \mathrm{~g} \mathrm{~L}^{-1}$ in the channel mouths and $1.8 \times 10^{-3} \mathrm{~g} \mathrm{~L}^{-1}$ inside the Santos Estuarine System, near the industrial pole of Cubatão (Moser et al., 2001). In the estuarine complex of CananéiaIguape and Bertioga, near pristine ecosystems, higher ammonium concentrations are related to the decomposition of organic matter, probably from the mangroves at their margins (S.M.F. Gianesella, IOUSP, Brazil, unpublished data). In the case of the Santos Estuarine System high ammonium concentrations may also be related to diffuse sewage discharges throughout the system and to fertilizer plants in Cubatão. These plants make an important contribution to the national production of fertilizers, importing 6.61 million tons of raw materials annually.

Estuarine morphology, circulation and regional climatic conditions affect the mean nutrient transport (Boynton et al. 1995). Generally, a nutrient transport outwelling pattern is observed in estuarine systems (Grelowski et al., 2000; Enqvist et al. 1996; Rodriguez, 1999; Boynton et al. 1995; Dame \& Allen, 1996; Uncles et al., 1998b). The Santos Estuarine System follows this pattern as regards salt, DIN and ammonium during periods of high baroclinic influence, such as at the neap tides in dry as well as rainy seasons. Apart from that phosphate increases followed flood events during the dry season. BarreraAlba et al. (2002) discussed a similar trend of phosphate distribution in the Cananéia inlet. According to these authors higher concentrations of phosphate in saltier waters were related to the trapping of this nutrient by the barotropic component.

The particulate matter generally remains in the systems and produces huge deposits of material inside the Santos Estuarine System (SONDOTECNICA, 1977), creating the need for dredging to maintain the operational depth of the port channel. Several studies have recently been undertaken on the flux and transport of suspended material, with numerical models in estuaries, coastal lagoons and laboratory simulations (e.g. Bronsdon \& Naden, 2000; Greenwood \& Shu, 2001; Dias et al., 2001; Green \& MacDonald, 2001; Wu et al., 2004). All of them have drawn attention to the sediment transport generated by barotropic forces (and consequently internal waves) as being the main factor involved in the silting up of estuarine systems. However, present results show ISM and OSM transport to the bay related to periods of high freshwater discharge (neap tides and rainy season). Probably the suspended material outwelling at Santos should be associated with massive sediment transport by the fluvial discharge, responsible for $64 \%$ of the total sediment inside this channel (according to SONDOTECNICA, 1977).

Estuarine morphodynamics reflect the relative balance between these processes. Sediment transport caused by fluvial discharge is not constant in time on space; an increase in the effects of erosion and in sediment transport from the rivers to the estuaries is generally related to a lack of vegetation on the tributaries margins, vegetation detritus, eolic material, anthropic disposal and suspension through navigation and dredging (Schoellhamer, 1996). Actually, the transport of suspended matter along the Santos and São Vicente channels, where the mangrove forests have been degraded, is similar to those of Cananéia inlet (Barrera-alba et al., 2002) where the mangrove forest has been preserved, and both are one order of magnitude greater than that of the Bertioga channel (Gianesella et al., 2000).

Despite the fact that the transport data in the present study were not recorded for complete tidal cycles, the results obtained have revealed the of magnitude of the processes observed and are in agreement with the description of the region: the continuous silting up of Santos harbor probably occurs as a result of the excess material that is not deposited in the upper reaches of the estuarine system. This may also be deduced from the SONDOTÉCNICA (1977) information that this material originates as fluvial discharge. Possibly the Santos channel drainage basin is subject to stronger processes of erosion than those of the São Vicente channel drainage basin. In fact the São Vicente mangroves have suffered less anthropic influence than those of the Santos channel which have been subject to more intense and haphazard urban occupation and destruction of natural vegetation.

The present results showed Chl- $a$ increasing at neap tides when nutrients, light availability and water column stability occur together. Several authors have described the relationship between phytoplankton biomass variations and water column stability (e.g. Demers et al., 1986; Gianesella et al., 2000). According to these authors, water column mixing generally favors phytoplankton biomass increases in environments limited in nutrients while stability favors the phytoplanktonic growth in environments limited in light.

There are few studies that consider the phytoplanktonic biomass balance between adjacent coastal systems (e.g. Heinle \& Flemer, 1976; Moll, 1977). Generally, these works have focused on transport between tidal flats and estuaries. The phytoplanktonic biomass transport observed in the Santos Estuarine System has followed the trend of particulate matter transport, exporting during periods of greater freshwater inflow (neap tides and rainy season) and importing on spring tides during the dry season. 
The maturity of an estuarine system may be characterized according to the marsh-estuarine continuum hypothesis (Dame et al., 1992), which states that a mature ecosystem exports particulate and dissolved material while an immature one imports both. During the dry season, the Santos Estuarine System has the characteristics of a middle-aged system since it exports dissolved materials and occasionally imports particulate ones. During the rainy season, the estuarine system may be characterized as a mature system, exporting both dissolved and particulate compounds.

Instantaneous transport obtained during the sampling period indicates exportation of DIN and ammonium into the bay in both dry and rainy seasons, exportation of ISM, OSM and Chl- $a$ during periods of higher freshwater discharge (neap tides and rainy season) and an inwelling of phosphate during the dry season. Even should the present results represent only extreme conditions, they indicate a large contribution of the Santos and São Vicente channels to the eutrophication of the Santos bay waters as a result of the nutrient input from the estuarine waters.

These results are corroborated by the maximum discharge of the submarine outfall located in Santos bay, that corresponds to $7 \mathrm{~m}^{3} \mathrm{~s}^{-1}$, while the Santos Estuarine System contributes to a volume transport as high as $10^{2}$ to $10^{3} \mathrm{~m}^{3} \mathrm{~s}^{-1}$. Comparing nutrients and chlorophyll concentration data to those of Gianesella-Galvão (1982), sampled in 1975, before the building of the submarine outfall and, further, with those presented by Moser et al. (2004), sampled in 1997 and 1998, 23 years after the submarine outfall construction, eutrophication levels in Santos bay may be seen still high, as shown by the similar concentrations of these variables. The present study clearly indicates that nutrients and Chl- $a$ balance between the estuaries and Santos bay reveal that the estuarine system still acts as one of the major eutrophication sources for this bay, especially in rainy periods.

\section{Conclusions}

This study indicates that: (1) transport of properties is related to pluviometric and tidal conditions, with important outwelling events during periods of greater freshwater discharge, neap tides and rainy seasons; (2) despite the estuarine retention of dissolved and particulate matter, the Santos Estuarine System represents an important source contributing to the eutrophication of the adjacent coastal area through the supply of nutrients, suspended matter and chlorophyll, especially during periods of higher freshwater discharge; (3) the Santos and São Vicente channels are the major eutrophication sources for the Santos bay, since the dissolved inorganic nutrients and Chl- $a$ values are similar to those discharged by the submarine outfall, and the flow is two or three orders of magnitude greater than that of the submarine outfall flow.

\section{AcKNOWLEDGMENTS}

This research was funded by Fundação de Amparo à Pesquisa do Estado de São Paulo (FAPESP, process $99 / 02-307-7 R$ ) and by a grant to Gleyci Moser from Conselho Nacional de Pesquisas (CNPq, process 141119/1998-5). We are grateful to Tomás Edison da Silva, Manoel Pereira and the crews of the R/V Prof. W. Besnard, Albacora and Véliger II, for their invaluable field work. We also thank the anonymous referees whose suggestions have enhanced the quality of this paper.

\section{REFERENCES}

APHA (AMERICAN PUBLIC HEALTH ASSOCIATION, inc.) 1985. Standard methods for the examination of water and wastewater. $16^{\text {th }}$ ed. Washington, D.C., APHA.

Aminot, A. \& Chaussepied, M. 1983. Manuel des analyses chimiques en mileu marin. Brest, Ed. C.N.E.X.O. 159 p.

Barrera-Alba, J. J.; Gianesella, S. M. F.; Harari, J.; Miranda, L. B.; Moser, G. A. O.; Nishihara, L.; Picarelli, S.; Saldanha-Corrêa, F. M. P.; Jakovac, A. C. \& Ricci, F. P. 2002. Transporte de ferro e silicato dissolvidos nas entradas do Sistema Estuarino Lagunar de CananéiaIguape, Julho 2001. In: CONGRESSO BRASILEIRO DE PESQUISAS AMBIENTAIS, $2^{\circ}$. Santos 2002. CDRom

Bérgamo, A. L.; Miranda, L. B. D \& Corrêa, M. A. 2002. Estuário: Programas para processamento e análise de dados hidrográficos e correntográficos. Relat. téc. inst. Oceanogr., S Paulo, 49:1-16.

Braga, E. S.; Bonetti, C. V. D. H.; Burone, L. \& Bonetti, J. F. 2000. Eutrophication and bacterial pollution caused by industrial and domestic wastes at Baixada Santista Estuarine System- Brazil. Mar. Pollut. Bull., 40(2):165173.

Bronsdon, R. K. \& Naden, P. S. 2000. Suspended sediment in the Rivers Tweed and Teviot. Sci. Total Environment, 251(255):95-113.

DAEE (Departamento de Águas e Energia Elétrica). 1999. Banco de dados pluviográficos do estado de São Paulo. IN: FUNDAÇÃO DO CENTRO TECNOLÓGICO DE HIDRÁULICA- USP. CD-ROOM.

Dame, R.F. \& Allen, D.M. 1996. Between estuaries and the sea. J. expl. Mar. Biol. Ecol., 200:169-185.

Dame, R. F., Childers, D. \& Koepfler, E. 1992. A geohydrologic continuum theory for the spatial and temporal evolution of marsh- estuarine ecosystems. Neth. J. Sea Res., 30:63-72.

Demers, S.; Legendre, L.; Therriault, J. C. 1986. Phytoplankton responses to vertical tidal mixing. In: Bowman, J.; Yentsch, M.; Peterson, W. T. eds. Lecture Notes on Coastal and Estuarine Studies. Berlin, Springer. 17:1-40.

Dias, J. M.; Lopes, J. F. \& Dekeyser, L. 2001. Lagrangian transport of particles in Ria de Aveiro Lagoon, Portugal. Phys. Chem. Earth, (B), 26 (9): 721-727. 
Eyre, B. 1998. Transport, retention and transformation of material in Australian Estuaries. Estuaries, 21(4):540551.

Eyre, B. \& Balls, P.1999. A comparative study of nutrient behavior along the salinity gradient of tropical and temperate estuaries. Estuaries, 22(2A):313-326.

Gianesella, S. M. F.; Saldanha-Corrêa, F. M. P. \& Teixeira, C. 2000. Tidal effects on nutrients and phytoplankton distribution in Bertioga channel, São Paulo, Brazil. Aquat. Ecossys. Health Manag., 3:533-544.

Gianesella-Galvão, S. M. F. 1982. Standing-stock and potential production of phytoplankton in the bay of Santos, Brazil. Bolm Inst. oceanogr., S Paulo, 31(2):8594.

Graham, J. E.; Barrett, N. S.; Graddon, D. J. \& Last, P. R. 2000. The conservation significance of estuaries: a classification of Tasmanian estuaries using ecological, physical and demographic attributes as a case study. Biol. Conserv., 92:383-397.

Grasshoff, K.;Ehrhardt, M. \& Kremling, K. 1983. Methods of seawater analysis. 2nd. Revised and extended ed. Wienhien Verlag Chemie. $419 \mathrm{p}$

Green, M. O. \& MacDonald, I. T. 2001. Processes during estuary infilling by marine sands on an embayment coast. Mar. Geol. 178: 11-37.

Greenwood, J. L. \& Shu, S. W. 2001. Size fraction by suspension transport: a large scale flume experiment with shoaling waves. Mar. Geol., 176:157-174.

Grelowski, A.; Pastuszak, M.; Sitek, S. \& Witek, Z. 2000. Budget calculations of nitrogen, phosphorus and $\mathrm{BOD}_{5}$ passing through the Oder estuary. J. mar. Sys., 25 : 221 237.

Harari, J. \& Camargo, R., 1997. Simulações da circulação de maré na região costeira de Santos (SP) com modelo numérico hidrodinâmico. Pesq. Nav., 10: 173-188.

Harari, J.; Camargo, R. \& Cacciari, P. L. 2000. Resultados da modelagem numérica hidrodinâmica em simulações tridimensionais das correntes de maré na Baixada Santista. Rev. bras. rec. Hidric., 5(2):71-87.

Heinle, D. R. \& Flemer, D. A. 1976. Flows of materials between poorly flooded tidal marshes and an estuary. Mar. Biol., 35:359-373.

Jeffrey, S. W. \& Humphrey, G. F. 1975. New spectrophotometric equations for determining chlorophylls a, b, c and c2 in higher plants, algae and natural phytoplankton. Biochem. Physiol. Pfl., 167:191194.

Jiang, W.; Pohlmann, T.; Sündermann, J.\& Feng, S. 2000. A modeling study of SPM transport in the Bohai Sea. J. mar. Sys., 24:175-200.

Miranda, L. B. de; Castro, B. M. de \& Kjerfve, B. 1998. Circulation and mixing due to tidal forcing in Bertioga channel, São Paulo, Brazil. Estuaries. 21(2):204-214.

Mitchell, S. B.; West, J. R.; Arundale, A. M. W.; Guymer, I. \& Couperthwaite, J. S., 1998. Dynamics of the turbidity maxima in the upper Humber Estuary System, UK. Mar. Pollut. Bull., 37:190-205.

Moll, R. A. 1977. Phytoplankton in a temperate zone saltmarsh: net production and exchange with coastal waters. Mar. Biol. 42:109-118.

Moser, G. A. O.; Cattena, C. O.; Gianesella, S. M. F.; Braga, E. de S. \& Aidar, E., 2001. Potencial de Crescimento Algal (PCA) utilizado como indicador de estágios de eutrofização em dois estuários tropicais eutrofizados. In:
Congresso Latino Americano sobre Ciências do Mar. Anais. Santos, 2001. CD-ROM.

Moser, G. A. O.; Gianesella, S. M. F.; Catenna, C. O.; David, C. J.; Barrera-Alba, J. J.; Saldanha-Corrêa, F. M. P. \& Braga, E. de S., 2002. Influencia das marés sobre o fitoplâncton no Sistema Estuarino de São Vicente e Santos. In: Congresso Brasileiro de Pesquisas Ambientais. Anais. 2. Santos, 2002. CD-ROM.

Moser, G. A. O.; Sigaud-Kutner, T. C. S.; Cattena, C. O.; Gianesella, S. M. F.; Braga, E. de S.; Schinke, K. P. \& Aidar, E., 2004. Algal growth potential as an index of eutrophication degree in coastal areas under sewage disposal influence. Aquat. Ecosys. Health Manag., 7(1):115-126

Pereira-Filho, J.; Schettini, C. A. F.; Rörig, L. \& Siege, E. 2001. Intratidal variation and net transport of dissolved inorganic nutrients, POC and chlorophyll a in the Cambiriú River Estuary, Brazil. Estuar. coast. Shelf Sci., 53:249-257.

Poole, H. H. \& Atkins, W. R. G. 1929. Photo-electric measurements of submarine illumination throughout the year. J. Mar. Biol. Assoc., 16, 297-324.

Rodriguez, G. 1999. The Maracaibo System: a physical profile. Estuaries of South America, their geomorphology and dynamics. In: Perillo, G. M. E.; Piccolo, M. C.; Pino-Quivira, M. New York, . SpringerVerlag, 15-33 p.

Schoellhamer, D. H. 1996. Anthropogenic sediment resuspension mechanisms in shallow microtidal estuaries. Estuar. coast. Shelf Sci., 43:533-548.

SONDOTECNICA, 1977. Comportamento hidráulico e sedimentológico do estuário santista. Ministério dos Transportes, Empresa de Portos do Brasil S. A., PETROBRAS e Instituto de Pesquisas HidráulicasINPH. 343 p.

Teal, J. M. 1962. Energy flow in the salt marsh ecosystem of Georgia. Ecology, 43: 614-624.

Uncles, R. J.; Easton, A. E.; Griffiths, M. L.; Harris, C.; Howland, R. J. M.; Joint, I.; King, R. S.; Morris, A. W.; Plummer, D. H. 1998a. Concentrations of suspended chlorophyll in the tidal Yorkshire Ouse and Humber estuary. Sci. total Environment, 210/211:367-375

Uncles, R. J.; Howland, R. J. M.; Easton, A. E.; Griffiths, M. L.; Harris, C.; King, R. S. Morris, A. W.; Plummer, D. H.; Woodward, E. M. S. 1998b. Concentrations of dissolved nutrients in tidal Yorkshire Ouse river and Humber estuary. Sci. total Environment, 210/211:377388.

UNESCO. 1981. The pratical salinity scale 1978 and the International equation of state of seawater 1980. Unesco tech. Pap. mar. Sci., 36:25 p.

Wu, Y.; Zhang, J.; Cho, K.W.; Hong, J. H.; Chung, C. S. 2004. Origin and transport of sedimentary organic matter in the Yalujiang Estuary, North China. Estuaries, 27(4):583-592.

(Manuscript received 15 April 2005; revised 19 October 2005; accepted 03 November 2005) 